\title{
AKTIVITAS ANTIBAKTERI DAN ANTIOKSIDAN FRAKSI DAUN Colocacia esculenta L. DENGAN METODE KLT-BIOAUTOGRAFI DAN DIFENILPIKRIL HIDRAZIL
}

\author{
Herwin, Muzakkir Baits, Ririn \\ Fakultas Farmasi Universitas Muslim Indonesia \\ Email : herwinfarmasi@gmail.com.
}

\begin{abstract}
The aim of the research to determine the antibacterial and antioxidant activity of Colocacia esculenta fraction leaves derive from Pare-Pare South Sulawesi in using TLC- Bioautography and diphenilpycril Hydroxil. Screening antibacterial activity test of the Colocacia esculenta fraction leaves exhibited in concentration $1 \%$ active on pathogenic bacteria Salmonella thypi. Based on either antibacterial and antioxidant activities by TLC-Bioautography showed that fraction at $R f 0.70$ value active on bacteria Salmonella thypi and antioxidant active as well. Identification of active chemical compound showed flavonoid compound using lodium-KI and antimo (III) clorida as reagent.
\end{abstract}

Key Words : Colocacia esculenta fraction leave, TLC-Bioautography and diphenilpycril hydroxil, antibacterial and antioxidant.

\section{PENDAHULUAN}

Penemuan berbagai senyawa obat baru dari bahan alam semakin memperjelas peran penting metabolit sekunder tumbuhan sebagai sumber bahan baku obat. Kandungan metabolit sekunder ini telah terbukti bekerja sebagai derivat antikanker, antibakteri dan antioksidan alami antara lain golongan alkaloid, tanin, golongan polifenol dan turunannya yang pemanfaatannya sebagai obat alami diyakini mempunyai efek samping yang relatif kecil dibandingkan obat modern. Maka dari itu senyawa metabolit sekunder tersebut dalam pemanfaatannya sangat diperlukan pengujian aktivitas dan pengujian pra-klinis bahkan secara klinik untuk mengetahui khasiat, dosis dan keamanan senyawa alami sebagai obat antibakteri.

Salah satu tumbuhan yang sangat kurang termanfaatkan secara ilmiah saat ini adalah daun Colocacia esculenta L. dari Pare-Pare Sulawesi Selatan yang dimanfaatkan sebagai obat radang, kulit bernanah, berak darah, bisul, dan luka bakardengan kandungan kimiasaponin, terpen, 
Aktivitas antibakteri dan antioksidan fraksi daun Colocacia esculenta L. dengan metode $K L T$-Bioautografi dan Difenilpikril hidrazil

tanin, flavonoid, flobatanin, antraquinon, glikosida jantung, dan alkaloid (Bhagyashree, 2011). Senyawa tersebut sangat potensial pemanfaatannya sebagai antibakteri alami untuk penanggulangan infeksi bakteri patogennamun secara ilmiah pemanfaatan daun Colocacia esculenta L.sebagai obat antibakteri alami belum terealisasikan.

Penelitian pendahuluan yang telah dilakukan adalah skrining, penelusuran golongan komponen kimia dan aktivitas antibakteri berdasarkan diameter zona hambatan pada konsentrasi ekstrak etanol dari daun Colocacia esculenta L. terhadap bakteri patogen Salmonella thypi sangat potensial digunakan sebagai antibakteri alami (Herwin, 2013). Dengan adanya aktivitas dan kandungan kimia ekstrak etanol daun Colocacia esculenta L. yang potensial sebagai senyawa bioaktif alami tersebut, sehingga diperlukan fraksinasi daun Colocacia esculenta $\mathrm{L}$. dalam penelusuran senyawa bioaktif sebagai antibakteri, antioksidan dan identifiasi golongan senyawa flavonoid sehingga penggunaannya dalam masyarakat lebih dapat dipertanggungjawabkan.

\section{METODE PENELITIAN}

\section{Tempat dan Waktu Penelitian}

Penelitian dilaksanakan di Laboratorium Mikrobiologi, Fitokimia, Fakultas Farmasi Universitas Muslim Indonesia dengan pengujian aktivitas antibakteri, antioksidan dan identiufikasi golongan senyawa aktif fraksi daun Colocacia esculenta L. Dan waktu penelitian dilaksanakan pada bulan juli-September 2015.

\section{Alat dan bahan yang digunakan}

Alat utama berupa timbangan analitik, rotavapor, sentrifuge, autoklaf, oven, laminar air flow (LAF), inkubator, spektofotometri UV-visible dan peralatan pendukung lainnya adalah bejana maserasi, botol pengencer, cawan petri, chamber, corong, corong pisah $500 \mathrm{ml}$, labu ukur $50 \mathrm{ml}$, lampu spiritus, timbangan kasar.

Bahan utama dalam penelitian ini, fraksi daun Colocacia esculenta L. dari Pare-Pare Sulawesi Selatan, aquadest, biakan murni bakteri patogen Salmonella thypi, ATTC 2014), kloroform p.a (E.Merck), nheksan p.a (E.Merk), etil asetat p.a (E.Merk), larutan $\mathrm{NaCl}$ fisiologis $0,9 \%$, medium GNA (Glukosa Nutrien Agar), medium NA (Nutrien Agar), medium NB (Nutrien Broth), metanol p.a, reagen semprot (Yodium $\mathrm{KI}$, 
Aktivitas antibakteri dan antioksidan fraksi daun Colocacia esculenta L. dengan metode $K L T$-Bioautografi dan Difenilpikril hidrazil

Dragondroff $\mathrm{HCL}$ dan Dragondroff Munier), difenilpikril hidrazil.

\section{Presedur Penelitian}

Daun Colocacia esculenta L. yang diperoleh dari Pare-Pare Sulawesi Selatan terlebih dahulu disortasi dengan tujuan untuk memisahkan kotoran-kotoran yang melekat pada sampel sehingga sampel yang dibutuhkan sesuai dengan yang diperlukan. Proses pemisahan kotoran dilakukan dengan air mengalir hingga bersih dan diangin-anginkan diudara bebas dan tidak terkena matahari secara langsung.Sampel yang diperoleh dideterminasi dan standarisasi simplisia untuk dilakukan ekstraksi secara maserasi. Daun Colocacia esculenta L. yang telah diolah ditimbang sebanyak 1245 g kemudian dimasukkan ke dalam bejana maserasi, selanjutnya ditambahkan metanol sampai terendam seluruh sampel, dan dibiarkan selama 5 hari dengan pengadukan beberapa kali. Setelah itu disaring dan ampasnya direndam kembali dengan cairan penyari yang baru sebanyak 2 kali. Hasil penyarian yang didapat lalu dipekatkan dengan menggunakan rotavapor sampai diperoleh ekastrak etanol kental.

\section{Fraksinasi Ekstrak Etanol Daun Colocacia esculenta L. Dengan Metode Kroatografi Cair Vakum}

Ekstrak etanol daun Colocacia esculenta L. ditimbang sebanyak 3 gram kemudian difraksinasi dengan metode kromatografi cair vakum menggunakan eluen n-heksan2×100 $\mathrm{ml}, \mathrm{n}$-heksan : etil asetat $(15: 1,10: 1$, $5: 1,1: 1,1: 5,1: 10,1: 15)$ etil asetat 100 $\mathrm{ml}$, etil asetat : metanol $(15: 1,10: 1$, $5: 1,1: 1)$, metanol $2 \times 100 \mathrm{ml}$. Hasil fraksinasi dilakukan aktivitas antibakteri dengan metode KLTBioautografi, identifikasi penampak bercak golongan flavanoid (pereaksi benedick, aluminium klorida, Yodium $\mathrm{KI}$, Dragondroff HCL dan Dragondroff Munier dan pengujian aktivitas antioksidan menggunakan metode DPPH.

\section{Skrining Aktivitas Fraksi Daun Colocacia esculenta L. Terhadap} Bakteri Patogen

Sebanyak $10 \mathrm{mg}$ fraksi daun Colocacia esculenta L. dilarutkan dalam $200 \mu \mathrm{l}$ DMSO $(200 \mu \mathrm{l}=0,2 \mathrm{ml})$ kemudian dituang dalam cawan petri yang berisi medium Nutrient Agar (NA) hingga memadat, lalu digoreskan suspensi bakteri dan diinkubasi pada suhu $37^{\circ} \mathrm{C}$ selama 24 jam. 
Aktivitas antibakteri dan antioksidan fraksi daun Colocacia esculenta L. dengan metode $K L T$-Bioautografi dan Difenilpikril hidrazil

Aktivitas Antioksidan Fraksi Etanol

Daun Colocacia esculenta L.

Dengan Metode Difenilpikril Hidrazil (DPPH)

\section{a. Pembuatan Larutan DPPH}

Ditimbang DPPH Kristal sebayak $50 \mathrm{mg}$, lalu dimasukkan kedalam labu takar100 ml, tambahkan etanol sampai batas sehingga diperoleh kosentrasi 0.05\%. Dari kosentrasi $0.05 \%$ tersebut, dipipet $8 \mathrm{ml}$ kemudian ditambahkan $100 \mathrm{ml}$ aquades hingga diperoleh kosentrasi $0.004 \%$.

\section{b. Pengujian Aktivitas antioksidan}

Kromatogram hasil elusi dari fraksi daun Colocacia esculenta L. disemprotkan pereaksi difenilpikril hidrazil (DPPH) pada kosentrasi 0.004\%. Hasil penyemprotan dengan DPPH diamati bercak aktif yang positif sebagai antioksidan berdasarkan bercak berwarna kuning pada sinar tampak kemudian dihitung nilai Rf-nya.
Pengujian Aktivitas Antibakteri Fraksi Daun Colocacia esculenta L. Terhadap Bakteri Salmonella thypi Dengan Metode Bioautography-TLC Fraksi Daun Colocacia esculenta L. ditimbang sebanyak 10 mg lalu dilarutkan dengan kloroform : metanol (1:1). Setelah larut ditotolkan pada lempeng kromatografi lapis tipis dengan ukuran lempeng untuk masing-masing ekstrak 1 × 6,5 cm dan dielusi dengan menggunakan $\mathrm{n}$ heksan : etil asetat (4:1). Setelah terelusi lempeng kromatografi fraksi daun Colocacia esculenta L., dikeluarkan dari chamber lalu dianginanginkan hingga cairan pengelusinya menguap. Kromatogram yang dihasilkan diamati pada sinar UV panjang gelombang $254 \mathrm{~nm}$ dan 366 $\mathrm{nm}$ dan dihitung nilai Rf-nya. Hasil kromatogram diletakkan di atas permukaan medium agar yang telah disuspensi dengan bakteri uji dan dibiarkan selama 60 menit. Setelah itu lempeng tersebut diangkat dan dikeluarkan. Selanjutnya media diinkubasi pada suhu $37^{\circ} \mathrm{C}$ selama $1 \mathrm{x}$ 24 jam (bakteri). 
Aktivitas antibakteri dan antioksidan fraksi daun Colocacia esculenta L. dengan metode $K L T$-Bioautografi dan Difenilpikril hidrazil

\section{HASIL PENELITIAN}

Tabel 1. Hasil Sortasi Daun Colocacia esculenta L. Asal Kabupaten Pare-Pare Sulawesi Selatan

\begin{tabular}{ccccc}
\hline No. & $\begin{array}{c}\text { Berat Tumbuhan } \\
\text { (gram) }\end{array}$ & $\begin{array}{c}\text { Berat Basah } \\
\text { (gram) }\end{array}$ & $\begin{array}{c}\text { Berat Kering } \\
\text { (gram) }\end{array}$ & $\begin{array}{c}\text { Kadar Air } \\
(\%)\end{array}$ \\
\hline 1. & 6250 & 4650 & 1245 & 26.8 \\
\hline
\end{tabular}

Tabel 2. Hasil Ekstraksi Simplisia Daun Colocacia esculenta L. asal kabupaten ParePare Sulawesi Selatan

No. Berat Simplisia (gram) Ekstrak Etanol (gram)

$1.1245 \quad 130$

Tabel 3. Hasil Fraksinasi Ekstrak etanol daun Colocacia esculenta L.Dengan Metode Kromatografi Cair Vakum

\begin{tabular}{|c|c|c|c|c|}
\hline \multirow{2}{*}{ Fraksi } & \multirow{2}{*}{ Bercak } & \multirow{2}{*}{ Rf } & \multicolumn{2}{|c|}{ Penampak Bercak } \\
\hline & & & UV 254 nm & UV $366 \mathrm{~nm}$ \\
\hline 1 & 1 & 0.95 & Ungu & - \\
\hline 2 & 1 & 0.70 & Ungu & Putih \\
\hline 3 & 1 & 0.70 & Ungu & Putih \\
\hline \multirow[t]{3}{*}{4} & 1 & 0.52 & Ungu & Putih \\
\hline & 1 & 0.95 & Ungu & - \\
\hline & 2 & 0.70 & Ungu & Putih \\
\hline \multirow{3}{*}{5} & 3 & 0.52 & Ungu & Putih \\
\hline & 4 & 0.38 & Ungu & Putih \\
\hline & 1 & 0.95 & Ungu & - \\
\hline \multirow{4}{*}{6} & 2 & 0.70 & Ungu & Putih \\
\hline & 3 & 0.52 & Ungu & - \\
\hline & 4 & 0.38 & Ungu & Putih \\
\hline & 1 & 0.95 & Ungu & - \\
\hline \multirow{3}{*}{7} & 2 & 0.70 & Ungu & Putih \\
\hline & 3 & 0.52 & Ungu & - \\
\hline & 4 & 0.38 & Ungu & Putih \\
\hline 8 & 1 & 0.95 & Ungu & - \\
\hline 9 & 1 & 0.95 & Ungu & - \\
\hline 10 & 1 & 0.95 & Ungu & - \\
\hline 11 & 1 & 0.95 & Ungu & - \\
\hline 12 & 1 & 0.95 & Ungu & - \\
\hline 13 & 1 & 0.95 & Ungu & - \\
\hline 14 & 1 & 0.95 & Ungu & - \\
\hline 15 & 1 & 0.95 & Ungu & - \\
\hline
\end{tabular}


Aktivitas antibakteri dan antioksidan fraksi daun Colocacia esculenta L. dengan metode $K L T$-Bioautografi dan Difenilpikril hidrazil

Tabel 4. Hasil skrining aktivitas antibakteri fraksi daun Colocacia esculenta L. terhadap bakteri patogen Salmonella typhi

No.

Sampel

Bakteri Uji

1. Fraksi Daun Colocacia esculenta L.

Salmonella thypi

Tabel 5. Hasil pengujian aktivitas antibakteri fraksi daun Colocacia esculenta L. secara KLT-Bioautografi

\begin{tabular}{cccccc}
\hline \multirow{2}{*}{ No. } & \multirow{2}{*}{ Rf } & \multicolumn{3}{c}{ Warna Bercak Pada } & \multirow{2}{*}{ Bakteri Uji } \\
\cline { 3 - 5 } & & UV 254 nm & UV 366 nm & $\mathbf{H}_{2} \mathbf{S O}_{4} \mathbf{1 0 \%}$ & \\
\cline { 3 - 5 } 1. & 0.70 & Hijau Muda & Ungu & Putih & Salmonella thypi
\end{tabular}

Tabel 6. Hasil pengujian aktivitas Antioksidan Fraksi Daun Colocacia esculenta L. Dengan Metode DPPH

\begin{tabular}{ccc} 
Nilai Rf & Warna Bercak & Pereaksi Kimia \\
\hline 0.70 & Kuning & Difenilpikril Hidrazil \\
\hline
\end{tabular}

Tabel 7. Hasil pengujian aktivitas antibakteri fraksi daun Colocacia esculenta L. secara KLT-Bioautografi

\begin{tabular}{cccc}
\hline \multirow{2}{*}{ Rf } & \multicolumn{2}{c}{ Penampak bercak } & \multirow{2}{*}{ Bakteri Uji } \\
\cline { 2 - 3 } & UV 254 nm & UV 366 nm & \\
\hline 0.70 & Hijau muda & Ungu & Salmonella thypi \\
\hline
\end{tabular}

\section{PEMBAHASAN}

Daun Colocacia esculenta L. yang diperoleh dari Pare-Pare Sulawesi Selatan disortasi dengan tujuan untuk memisahkan kotorankotoran yang melekat pada sampel sehingga sampel yang dibutuhkan sesuai dengan yang diperlukan. Proses pemisahan kotoran dilakukan dengan air mengalir hingga bersih dan diangin-anginkan diudara bebas dan tidak terkena matahari secara langsung kemudian ekstraksi secara maserasi.
Berdasarkan hasil sortasi Daun Colocacia esculenta L. diperoleh berat tumbuhan talas 6250 gram, 4650 gram berat basah dengan berat kering sebanyak 1245 gram. Simplisia kering sebanyak $1245 \mathrm{~g}$ diekstraksi dengan metode maserasi menggunakan etanol 96\% diperoleh $130 \mathrm{~g}$ ekstrak etanol kering.

Ekstrak etanol daun Colocacia esculenta L. ditimbang sebanyak3 gram kemudian difraksinasi dengan metode kromatografi cair vakum menggunakan eluen n-heksan 2x100 
Aktivitas antibakteri dan antioksidan fraksi daun Colocacia esculenta L. dengan metode $K L T$-Bioautografi dan Difenilpikril hidrazil

ml, n-heksan : etil asetat (15:1, 10:1, $5: 1,1: 1,1: 5,1: 10,1: 15)$ etil asetat 100 $\mathrm{ml}$, etil asetat : metanol (15:1, 10:1, $5: 1,1: 1)$, metanol $2 \times 100 \mathrm{ml}$. Fraksi daun Colocacia esculenta L. yang diperoleh darihasil fraksinasi dengan metode kromatografi cair vakum, dilakukan pengujian aktivitas antioksidan dengan metode DPPH menggunakan eluen $\mathrm{n}$-heksan : etil asetata (4:1) diperoleh nilai $\operatorname{Rf} 0.70$.

Hasil skrining aktivitas antibakteri secara dilusi padat fraksi daun talas (Colocacia esculenta L.) terhadap bakteri patogen Salmonella thypi diperoleh hasil bahwa ekstrak fraksi daun talas menunjukkan aktivitas terhadap bakteri Salmonella thypi. Berdasarkan hasil pengujian aktivitas antibakteri dan antioksidan dengan metode KLT-Bioautografi menggunakan eluen n-heksan : etil asetata (4:1) menunjukkan bahwa fraksi daun Colocacia esculenta L. dengan nilai $\mathrm{Rf}$ sebesar 0.70 aktif terhadap bakteri Salmonella thypi dan aktif sebagai antioksidan menggunakan pereaksi difenilpikril hidrazil serta hasil identifikasi golongan senyawa aktif menunjukan adanya golongan senyawa flavonoid menggunakan pereaksi Yodium KI, Dragondroff $\mathrm{HCL}$ dan Dragondroff Munier.

\section{KESIMPULAN}

Berdasarkan hasil penelitian disimpulkan bahwa :

1. Hasil pengujian aktivitas antibakteri fraksi daun Colocacia esculenta L. secara KLT-Bioautografi aktif terhadap bakteri Salmonella thypi dengan nilai $\mathrm{Rf} 0.70$ dan hasil identifikasi golongan senyawa akfit menunjukkan bahwa fraksi daun Colocacia esculenta L. Menunjukkan adanya golongan senyawa flavonoid menggunakan pereaksi kimia Yodium KI, Dragondroff HCL dan Dragondroff Munier.

2. Hasil pengujian aktivitas antioksidan bahwa fraksi aktif daun Colocacia esculenta L. aktif sebagai antioksidan pada nilai $\mathrm{Rf} 0.70$.

\section{DAFTAR PUSTAKA}

Bhagyashree R.P., 2011. Antihepatotoxic Activity Of Colocasia esculenta Leaf Juice. International Journal of Advanced Biotechnology and Research 2(2) : 296-304

Dalimatra, S., 2006. Atlas Tumbuhan Obat Indonesia. Jilid 4. Puspa Swara: Jakarta, Indonesia. $124 p$

DitJen POM, 1979. Farmakope Indonesia. Edisi III, Departemes Kesehatan Republik Indonesia, Jakarta. 1031p

DitJen POM, 1980, Farmakope Indonesia. Edisi IV, 
Aktivitas antibakteri dan antioksidan fraksi daun Colocacia esculenta L. dengan metode $K L T$-Bioautografi dan Difenilpikril hidrazil

Departemes Kesehatan

Republik Indonesia, Jakarta. 1290p

Eddy, Nabuk, O., 2009. Inhibitive and Adsorption Properties of Ethanol Extract of Colocasia esculenta Leaves for The Corrosion of Mild Steel in H2SO4. Int. J. Phys. Sci., 4(4). 165-171.

Herwin, 2013. Skrining dan Penelusuran Golongan Komponen Kimia Aktif Ekstrak Etanol Daun Colocacia esculenta L. Terhadap Beberapa Mikroba Uji Secara KLT-Bioautografi, Fakultas Farmasi UMI, Makassar. 35p

Kusumo, S., Hasanah, M., dan Moeljopawiro, S., 2002. Panduan Karakterisasi dan Evaluasi Plasma Nutfah Talas. Bogor : Departemen Pertanian Badan Penelitian dan
Pengembangan Pertanian

Komisi Nasional Plasma Nutfah. 83p

Leong, A.C., Yoshinori, K., Masakuni, T., Hironori I., Hirosuke, O., dan Hajime, T., 2009. Flavonoid glycosides in the shoot system of Okinawa Taumu (Colocasia esculenta S.). J. Food Chem. 07(004).166-172.

Sampurno, 2003. Kebijakan Pengembangan Obat Bahan Alam Indonesia Seminar Nasional Tumbuhan Obat Indonesia XXIII, Universitas Pancasila, Jakarta.83p

Yuliani, S., 2001. Prospek Pengembangan Obat Tradisional Menjadi Obat Fitofarmaka. Jurnal Litbang Pertanian, Balai Penelitian Tanaman Rempah dan Obat, Bogor, Indonesia. 121-133 